\title{
Agata Olechnowicz-Szewczyk
}

Department of Microeconomics, Faculty of Economics

University of Gdańsk

e-mail: agata.olechnowicz@ug.edu.p1

ORCID: 0000-0001-6462-1517

\section{Elżbieta Babula}

Department of Microeconomics, Faculty of Economics

University of Gdańsk

e-mail: elzbieta.babula@ug.edu.pl

ORCID: 0000-0002-7526-2414

\section{BEHAVIOURAL FACTORS OF WILLINGNESS TO SAVE LONG TERM - A FACTOR ANALYSIS}

DOI: $10.15611 /$ pn.2021.2.07

JEL Classification: G410

(C) 2021 Agata Olechnowicz-Szewczyk, Elżbieta Babula

This work is licensed under the Creative Commons Attribution-ShareAlike 4.0 International License. To view a copy of this license, visit http://creativecommons.org/licenses/by-sa/4.0/

Quote as: Olechnowicz-Szewczyk, A., \& Babula, E. (2021). Behavioural factors of willingness to save long term - a factor analysis. Prace Naukowe Uniwersytetu Ekonomicznego we Wrocławiu, 65(2).

\begin{abstract}
The study conducted an exploratory factor analysis of the Willingness to Save Long Term Scale (WSL). It developed a set of 30 appropriate and homogeneous items on behavioural aspects of willingness to save long term. It also determined the reliability indices of the scale and established its factor structure. The study population comprised 232 students from the Faculty of Economics at the University of Gdańsk. The outcome was subjected to Exploratory Factor Analysis (EFA) with oblimin rotation. The results of the EFA revealed that, with $\mathrm{KMO}>0.8$, the data were sufficient to undergo a factor analysis, while Bartlett's test $(\mathrm{p}<0.001)$ revealed a satisfactory EFA. The reliability coefficient Cronbach's $\alpha$ was statistically significant (0.719), indicating a high degree of internal consistency. The study concluded that the WSL Scale instrument was valid and reliable for measuring the phenomenon of willingness to save long term from the behavioural perspective. The five factors revealed by the EFA could be used as a guide to better understand how the decision-making process to save for retirement works.
\end{abstract}

Keywords: long-term savings, willingness to save, exploratory factor analysis (EFA), behavioural economics.

* This study was funded by the National Science Centre (Poland), by the funds assigned on the basis of decision no. 2017/27/N/HS4/01663. 


\section{Introduction}

Nowadays, demographic changes are among the greatest challenges facing the majority of countries. Extended lifespans and falling birth rates mean that people aged $60+$ will constitute more than $30 \%$ of the European population by 2050 . United Nations (UN) forecasts identify Europe as the fastest ageing continent on Earth. This phenomenon is called the silver tsunami, which will affect not only the development of the senior economy but also - or maybe even above all - retirement systems.

The aforementioned silver tsunami trend is also impacting on Poland. The Polish Central Statistical Office (GUS) predicts that the number of persons aged $65+$ will increase from 6.25 million in 2017 (16.5\% of the population) to 8.35 million in 2035 ( $23 \%$ of the population). This will undoubtedly increase the burden on the Polish pension system. According to the estimates of the Polish Central Bank (NBP), the probability that a retired person will collect a minimum pension in 2060 is $25 \%-50 \%$ (compared to $1 \%$ at present). These pension forecasts are more than aworrying, therefore economically active people should seek additional strategies to secure an adequate standard of living post-retirement. However, the alarming data show that in Poland, voluntary long-term savings are among the lowest in Europe. Moreover, Czapiński and Góra (2016) report a low level of Poles' retirement awareness. This is mainly manifested in the fact that, despite having knowledge about the risk of receiving low pensions based only on the mandatory pillar and the opportunity to save, Poles neglect to do so.

The problem that stems directly from the low willingness to save is, first of all, the question of how to mobilize additional retirement savings. In particular, in light of the recent changes in the Polish retirement system, it may be essential to understand Poles' attitudes towards pension security and to diagnose the non-economic factors that affect the intention (or lack thereof) to ensure long-term savings.

In view of these facts, the authors find it important to identify Poles' behavioural determinants regarding long-term savings. To do so there is a need to construct a scale that would allow to measure the individual characteristics related to factors influencing the decision-making process concerning long-term savings. This article presents the first step of developing such a scale, which includes constructing a questionnaire and conducting a factor analysis. Thus the main goal of this research was to establish the factors that would allow to develop a scale to measure information avoidance and the willingness to save long-term.

It is common practice to construct an original scale based on the two-step approach, i.e. conducting the questionnaire on a homogeneous group of students first, and on the target population sample in the second step, which allows for the proper modification of the scale in the first step of research (Ho, Hagmann, \& Loewenstein, 2020). Although young people are not characterized by a significant propensity to save for retirement, the choice of students as research subjects in the first step of constructing the scale is methodologically justified, and allows for 
selecting factors and verifying the correctness of the constructed original questionnaire. In such a research setup, there is no intention to generalize the obtained results to the population without further tests.

In order to achieve this goal, critical literature analysis and exploratory factor analysis of the questionnaire were employed. To verify factors, the developed questionnaire was distributed, and then data collection was conducted. The rest of the article is organized as follows: in the next section, the aspects of the long-term saving decision process are discussed in relation to the literature review. Next, the development and validation process of the Willingness to Save Long Term Scale (WSL). is described, followed by an analysis of how well the scale predicted the phenomena it intended to measure. Finally, the results reveal that five subscales Confidence in the Pension System, Retirement Anxiety and Emotional Stress, Trust in the Pension System, Attitudes toward Retirement and Long-term Savings and Personal Involvement in Retirement Finances - are the factors that can affect the decision-making process regarding long-term savings. These results correspond well with the conceptual framework and confirm the effective structure of the authors' questionnaire.

\section{Behavioural aspects of the decision-making process concerning long-term savings}

The economic approach to explaining saving behaviour has been evolving since the 1950s. Initially, it considered saving decisions to be optimization problems of rational decision-makers who maximize their utility. Both Friedman's permanent income hypothesis and the life-cycle hypothesis proposed by Modigliani and Brumberg assume that people can determine the optimum level of saving at any period (Varian, 2010). Later on, we witnessed the increasing popularity of concepts focused on describing actual behaviour. This approach resulted in the development of bounded rationality theory and behavioural economics. The behavioural hypothesis of a life cycle was one of the first theories to introduce psychological variables into the savings model. This hypothesis was proposed by Thaler and Shefrin (1981), who introduced new aspects, such as self-control and mental accounting, into the saving model.

Other researchers have tried to analyse the reasons and psychological factors that affect one's propensity to save. This growing interest in individual saving decisions was caused mainly by a decreasing saving rate. Ballinger et al. (2011) reported that one of the main and basic reasons for low involvement in the long-term saving decision-making process is the lack of economic knowledge and understanding of economic concepts. Therefore the recipe for a higher level of voluntary savings seems to involve acquiring the necessary knowledge about the possibilities of accumulating additional funds as part of individual retirement accounts or individual retirement security accounts. This statement seems to be particularly important in Poland, which in recent years has seen countless changes in the organization and 
functioning of the pension system, such as introducing the novelty of employee capital plans. Undoubtedly, these changes make the search for knowledge even more difficult and may discourage people from learning about the pension system. This, in turn, runs counter to the economic perspective of the decision-making process, which assumes that no useful information should ever be consciously ignored, as it can support the decision-making process (Golman, Hagman, \& Loewenstein, 2017).

Nevertheless, not only knowledge and financial planning skills, but also personal attitudes toward saving affect the individual savings rate (Ameriks, Caplin, \& Leahy, 2003; Elder \& Rudolph, 1999; Glasman \& Albarracin, 2006; Gough \& Sozou, 2005). Feelings about the functioning of the entire pension system are also not insignificant to shaping this attitude. According to Katona (1975), the optimism or pessimistic vision of the future determines the propensity to save money. Attitudes towards old age, and positive and negative feelings about retirement may significantly affect the process of making savings decisions (Hershfield, Goldstein, Sharpe, Fox, Yeykelis, Carstensen, \& Bailenson, 2011). Negative emotions towards retirement may result from unpleasant thoughts and pessimistic notions of the future concerning, e.g. financial dependence, ageing, disease, disability, and death (Weber, 2004). Such thoughts may endanger a person psychologically, causing so-called retirement anxiety (Hayslip, Bezerlein, \& Nichols, 1997). Nevertheless, little research has been carried out on decision-making regarding long-term saving and the role of anxiety in this process (Akpochafo, 2005; Clifford, Ogbebor, \& Enakpoya, 2010). The sense of anxiety may trigger the defensive strategy of avoiding a feared situation or stimulus, which may result in avoiding not only taking any action in this respect, but also any and all information about it. This thesis is confirmed in the research by Neukam and Hershey (2003), which indicated that persons who experience retirement anxiety are less ready to make decisions to join pension funds or save for the future. Taking all the above into account, the conceptual framework of the WSL Scale is based on five key behavioural biases: retirement anxiety, attitudes toward retirement and longterm savings, trust in the pension system, level of confidence in the pension system and personal involvement in retirement finances.

Such interdisciplinary research employing psychological tools to explain economic problems are gaining in popularity (see: Ho et al., 2020; Barrafrem, Västfjäll, \& Tinghög, 2020).

\section{Questionnaire development and data collection}

The scale development procedure is based on the guidelines of Carpenter (2018).

Regarding the authors' original scale development, in the first stage of the process, the conceptual framework of the scale was defined. After extensive research of each of the theoretical concepts, a pool of statements potentially measuring individual differences in the extent and behavioural aspects of the process of decision-making regarding long-term saving was created. 
Table 1. Questionnaire

\begin{tabular}{|c|c|}
\hline Item & Retirement anxiety subscale \\
\hline 1. & Long-term financial planning is very stressful for me. \\
\hline 2. & $\begin{array}{l}\text { Even my day-to-day spending decisions are a heavy burden for me, let alone financial retirement } \\
\text { planning. }\end{array}$ \\
\hline 3. & Thinking about retirement stirs up a lot of negative feelings in me. \\
\hline 4. & $\begin{array}{l}\text { Media reports about the inevitable need to plan for retirement beyond compulsory contributions } \\
\text { make me anxious. }\end{array}$ \\
\hline 5. & I am afraid that my pension will be much lower than that of my parents or grandparents. \\
\hline \multirow[t]{2}{*}{6.} & $\begin{array}{l}\text { I am aware that, without additional savings, in several dozen years it will be very difficult for me to } \\
\text { have an acceptable quality of life and this vision scares me. }\end{array}$ \\
\hline & Trust in the pension system subscale \\
\hline 7. & The state is able to adequately secure my retirement future. \\
\hline 8. & Saving in the third pillar will certainly not improve my standard of living in retirement. \\
\hline 9. & Social Security (ZUS) is a stable institution with a long history; therefore, it can be trusted. \\
\hline 10. & $\begin{array}{l}\text { Saving in the third pillar is pointless as it generates profits only for private institutions and not for } \\
\text { citizens. }\end{array}$ \\
\hline 11. & $\begin{array}{l}\text { Employee Capital Plans are a good idea to introduce changes to the pension system currently in } \\
\text { force in Poland. }\end{array}$ \\
\hline \multirow[t]{2}{*}{12.} & I do not trust pension products offered by financial institutions. \\
\hline & Attitudes toward retirement and long-term savings subscale \\
\hline 13. & It is primarily the state that should ensure that its citizens have financial security in their old age. \\
\hline 14. & $\begin{array}{l}\text { It is primarily citizens who should independently take care of ensuring their financial security in } \\
\text { old age. }\end{array}$ \\
\hline 15. & Children should help their elderly parents financially. \\
\hline 16. & I feel personally responsible for ensuring that I have a sufficient income during my retirement years. \\
\hline 17. & $\begin{array}{l}\text { Each working person should be able to decide for him or herself whether and how much to spend on } \\
\text { insurance, being aware that this will affect the amount of his or her future pension. }\end{array}$ \\
\hline \multirow[t]{2}{*}{18.} & $\begin{array}{l}\text { Systematic putting aside money, even small amounts, will have a positive effect on improving my } \\
\text { quality of life in retirement. }\end{array}$ \\
\hline & Confidence in the pension system subscale \\
\hline 19. & I know more than my peers about how to financially prepare for retirement. \\
\hline 20. & I understand very well the mechanism of the current pension saving system in Poland. \\
\hline 21. & Lack of sufficient income prevents me from saving extra for retirement. \\
\hline 22. & In financial matters, I do not feel competent enough to properly prepare for my retirement. \\
\hline 23. & I have a very good idea of the total value of all my personal retirement savings. \\
\hline \multirow[t]{2}{*}{24.} & I am still too young to be able to deal with the issues of financial preparation for retirement. \\
\hline & Personal involvement in retirement finances subscale \\
\hline 25. & $\begin{array}{l}\text { Active financial planning of one's own retirement pension is necessary from the moment of first } \\
\text { employment. }\end{array}$ \\
\hline 26. & Planning of financial security for retirement is best started only after the age of 40 . \\
\hline 27. & I have a well-thought-out strategy on how to plan my personal finances to cover my retirement. \\
\hline 28. & $\begin{array}{l}\text { If I do not start my financial preparation for retirement early enough, I will waste my chance of a } \\
\text { decent life in retirement. }\end{array}$ \\
\hline 29. & Deciding on additional pension insurance requires a lot of effort. \\
\hline 30. & In terms of my personal finances, I don't plan my future - I live from day to day. \\
\hline
\end{tabular}

Source: own study. 
The questionnaire (originally in Polish) was targeted to measure potential characteristics determining the individual long-term saving rate. This scale consisted of the five above-mentioned subscales: retirement anxiety, trust in the pension system, attitudes toward retirement and long-term savings, level of confidence in the pension system, and personal involvement in retirement finances. Each of the subscales consisted of six items which are presented in Table 1.

The items of the retirement anxiety subscale were adapted from the Social Components Retirement Anxiety Scale (Oluseyi \& Olufemi, 2015) and the others are the authors' original development. The statements were also revised on the basis of the pilot study. The responses for each of the 36 statements were measured on a fivepoint Likert scale ranging from "Strongly Agree" to "Strongly Disagree".

The questionnaire also included questions about social and demographic data like sex, age, education, income, and questions that assess the level of financial education and any saving actions taken.

The survey was run as an online questionnaire, for which 232 respondents were recruited among the students from the Faculty of Economics at the University of Gdańsk. A request to return the questionnaire was distributed via e-mail as well as on social media.

The average age of the respondents was $23 ; 56 \%$ of respondents were women and $44 \%$ were men. The majority of the survey participants $(76.3 \%)$ were employed or professionally active. A total of $66.8 \%$ of the survey respondents were residents of a city with 100,000 or more inhabitants.

\section{Exploratory factor analysis}

Factor analysis is a method of reducing the original set of variables to a smaller number of variables, called factors. Factors are considered to be a more basic dataset to which other explanatory properties can be attributed. Moreover, this method provides the possibility to interpret the relationship variables among themselves (Bandalos, 1993). In this study, the authors used an exploratory factor analysis to investigate the factor structure of the WSL scale by analysing the relationships between items.

The obtained results were subjected to a statistical analysis to estimate the reliability and accuracy of the questionnaire. The internal consistency of the scale was checked by calculating the alpha reliability coefficients using the SPSS software. For all the 36 items, the overall Cronbach's $\alpha$ coefficient was 0.719 . However, the elimination of four items improved the coefficient substantially to 0.756 , which is satisfactory. Finally, 26 items were analysed.

First, the factorability of the data was verified using the Kaiser-Meyer-Olkin (KMO) measure of sampling adequacy and Bartlett's test of sphericity. The obtained statistics are presented in Table 2. 
Table 2. KMO and Bartlett's test

\begin{tabular}{|l|l|r|}
\hline \multicolumn{2}{|c|}{ Kaiser-Meyer-Olkin Measure of Sampling Adequacy } & .812 \\
\hline \multirow{3}{*}{ Bartlett's Test of Sphericity } & Approx. Chi-Square & 1924.034 \\
\cline { 2 - 3 } & df & 325 \\
\cline { 2 - 3 } & Sig. & .000 \\
\hline
\end{tabular}

Source: own study.

Table 3. Total Variance Explained

\begin{tabular}{|c|c|c|c|c|c|c|}
\hline Factor & \multicolumn{3}{|c|}{ Initial eigenvalues } & \multicolumn{3}{|c|}{ Extraction sums of squared loadings } \\
\hline & total & $\%$ of variance & cumulative $\%$ & Total & $\%$ of variance & cumulative $\%$ \\
\hline 1 & 6.292 & 24.201 & 24.201 & 6.292 & 24.201 & 24.201 \\
\hline 2 & 2.446 & 9.407 & 33.608 & 2.446 & 9.407 & 33.608 \\
\hline 3 & 1.735 & 6.674 & 40.282 & 1.735 & 6.674 & 40.282 \\
\hline 4 & 1.520 & 5.847 & 46.129 & 1.520 & 5.847 & 46.129 \\
\hline 5 & 1.275 & 4.906 & 51.034 & 1.275 & 4.906 & 51.034 \\
\hline 6 & 1.097 & 4.221 & 55.255 & 1.097 & 4.221 & 55.255 \\
\hline 7 & 1.063 & 4.087 & 59.342 & 1.063 & 4.087 & 59.342 \\
\hline 8 & .990 & 3.809 & 63.152 & - & - & - \\
\hline 9 & .882 & 3.392 & 66.544 & - & - & - \\
\hline 10 & .855 & 3.288 & 69.832 & - & - & - \\
\hline 11 & .825 & 3.174 & 73.006 & - & - & - \\
\hline 12 & .786 & 3.022 & 76.029 & - & - & - \\
\hline 13 & .688 & 2.645 & 78.674 & - & - & - \\
\hline 14 & .630 & 2.425 & 81.099 & - & - & - \\
\hline 15 & .595 & 2.287 & 83.386 & - & - & - \\
\hline 16 & .543 & 2.088 & 85.474 & - & - & - \\
\hline 17 & .516 & 1.984 & 87.458 & - & - & - \\
\hline 18 & .500 & 1.922 & 89.380 & - & - & - \\
\hline 19 & .446 & 1.715 & 91.095 & - & - & - \\
\hline 20 & .431 & 1.659 & 92.754 & - & - & - \\
\hline 21 & .396 & 1.523 & 94.277 & - & - & - \\
\hline 22 & .387 & 1.489 & 95.766 & - & - & - \\
\hline 23 & .336 & 1.294 & 97.060 & - & - & - \\
\hline 24 & .282 & 1.085 & 98.145 & - & - & - \\
\hline 25 & .272 & 1.048 & 99.193 & - & - & - \\
\hline 26 & .210 & .807 & 100.000 & - & - & - \\
\hline
\end{tabular}

Source: own study. 
Regarding $\mathrm{KMO}$, conducting the factor analysis is sensible when the obtained value is larger than 0.5 . In other words, coefficient values above 0.5 justify a reduction of variables for the analysed sample in which 0.5 is the acceptable lower limit, however, a more accurate threshold is 0.6. In this study, the KMO measure of sampling adequacy is 0.812 . Bartlett's sphericity test was also statistically significant $(p<0.001)$, therefore both indicators justify conducting the exploratory factor analysis to extract common dimensions.

Next, to decide about the number of factors to be retained for rotation, most commonly the Kaiser criterion is used (which states that all the factors with eigenvalues greater than 1 should be included). Initially the authors also considered the Kaiser criterion for factor extraction, and determined the number of factors based on the eigenvalues. Seven factors with eigenvalues over 1 were extracted, accounting for $59.3 \%$ of the variance. The test results are presented in Table 3 .

The above-mentioned Kaiser criterion is widely used in research utilising factor analysis, but it will not always yield the best results for a particular data set. Deciding on the correct number of factors is a real challenge and has been the subject of many studies in recent years. A growing number of researchers support the conclusion that it is better to think in terms of the "most appropriate" rather than the "correct" number of factors (Bentler, 2000). This problem turned out to be also valid in the analysed results. After the oblimin rotation, in two factors every item had split loadings on another factor. For these reasons, the seven-factor solution did not appear to be the best representation of the structure of the WSL Scale. An examination of the scree plot, in search of a change in the slope of the line connecting the eigenvalues of the factors, indicated that the biggest change in slope came after the fifth or sixth factor (see Figure 1).

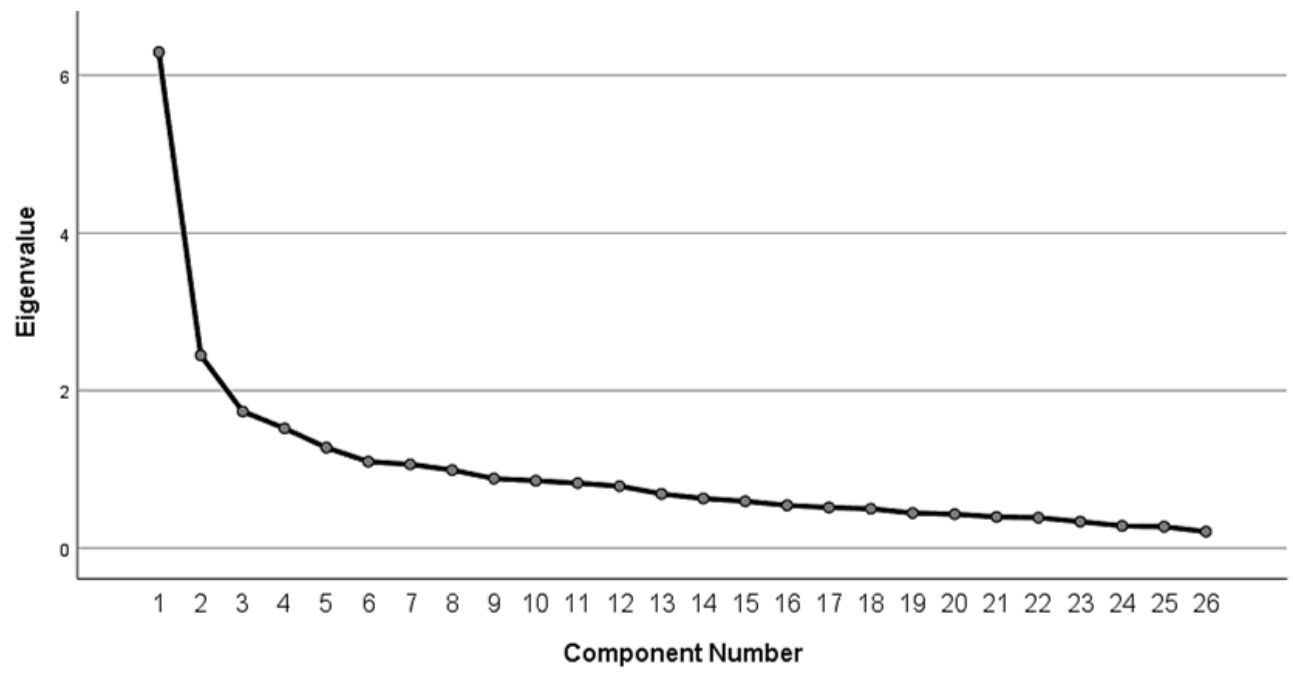

Fig. 1. Scree Plot

Source: own study. 
As a result, two additional exploratory analyses were run, setting different numbers of factor constraints, starting with six and going down to five. All of these analyses were conducted using principal axis factoring with oblimin rotation. The oblimin rotation was maintained, because in the first analysis several of the factors showed correlations above 0.20 , large enough to justify use of an oblique rotation (see Table 4).

Table 4. Component correlation matrix

\begin{tabular}{|c|c|c|c|c|c|c|c|}
\hline Factor & 1 & 2 & 3 & 4 & 5 & 6 & 7 \\
\hline $\mathbf{1}$ & 1.000 & -.176 & .163 & $\mathbf{- . 2 4 9}$ & $\mathbf{- . 2 4 9}$ & -.129 & $\mathbf{. 2 9 0}$ \\
\hline $\mathbf{2}$ & -.176 & 1.000 & -.057 & .052 & $\mathbf{. 2 1 2}$ & -.127 & -.057 \\
\hline $\mathbf{3}$ & .163 & -.057 & 1.000 & -.046 & -.106 & -.031 &. $\mathbf{2 0 7}$ \\
\hline $\mathbf{4}$ & $\mathbf{- . 2 4 9}$ & .052 & -.046 & 1.000 & $\mathbf{. 2 0 8}$ & .076 & -.137 \\
\hline $\mathbf{5}$ & $\mathbf{- . 2 4 9}$ & $\mathbf{. 2 1 2}$ & -.106 & $\mathbf{. 2 0 8}$ & 1.000 & -.070 & -.169 \\
\hline $\mathbf{6}$ & -.129 & -.127 & -.031 & .076 & -.070 & 1.000 & -.123 \\
\hline $\mathbf{7}$ & $\mathbf{. 2 9 0}$ & -.057 & $\mathbf{. 2 0 7}$ & -.137 & -.169 & -.123 & 1.000 \\
\hline
\end{tabular}

Source: own study.

After each analysis, the rotated factor loadings for each item were examined. Both the six and five-factor solutions were initially problematic. Items should be eliminated if they do not have a loading of at least 0.30 , a commonly used cutoff, with any one factor or if two factors have a division of items within the factor. The division was apparent because the loadings were positive for one group of items, and negative for the other group of items, and because one group of items had high loadings on only that factor, while the other group had lower loadings on that factor and substantial loadings on another factor. However, after eliminating six problematic items (items 5, 6, 13, 18,24, and 30), guided by the scientific principle of "truth and beauty" (Mcallister, 1989), the decision was made that the five-factor solution most adequately represents the analysed set of data.

Researchers have suggested varying numbers of items per factor, ranging from three to five, to represent each factor (MacCallum, Widaman, Zhang, \& Hong, 1999; Raubenheimer, 2004). This principle worked well in the proposed solution (see Table 5). Factor one consists of five items (19, 20, 22, 23, 27) and, after interpretation, can be labelled as Confidence in the pension system. Factor two consists of six items $(1,2,3,4,21,29)$ that can be named Retirement anxiety and emotional stress. Factor three consist of three items $(8,10,11)$ which form the subscale of Trust in the pension system. Factor four consists of three items $(14,16,17)$ which describe a subscale of Attitudes toward retirement and long-term savings. Finally, factor five consists of three items $(25,26,28)$ that can be named Personal involvement in retirement finances. 
Table 5. Pattern Matrix

\begin{tabular}{|c|c|c|c|c|c|}
\hline \multirow[t]{2}{*}{ Item } & \multicolumn{5}{|c|}{ Factor } \\
\hline & 1 & 2 & 3 & 4 & 5 \\
\hline 20 & .806 & - & - & - & - \\
\hline 19 & .754 & - & - & & - \\
\hline 23 & .721 & - & - & - & - \\
\hline 27 & .655 & - & - & - & - \\
\hline 22 & .593 & - & - & - & - \\
\hline 3 & - & .687 & - & - & - \\
\hline 2 & - & .680 & - & - & - \\
\hline 21 & - & -.679 & - & - & - \\
\hline 4 & - & .613 & - & - & - \\
\hline 1 & - & .594 & - & - & - \\
\hline 29 & - & -.593 & - & - & - \\
\hline 10 & - & - & .780 & - & - \\
\hline 8 & - & - & .755 & - & - \\
\hline 11 & - & - & .584 & - & - \\
\hline 17 & - & - & - & .749 & - \\
\hline 14 & - & - & - & .713 & - \\
\hline 16 & - & - & - & .693 & - \\
\hline 28 & - & - & - & - & -.732 \\
\hline 25 & - & - & - & - & -.727 \\
\hline 26 & - & - & - & - & -.494 \\
\hline
\end{tabular}

Source: own study.

The obtained results correspond with the conceptual framework and confirm the effective structure of the questionnaire items for studying the phenomena in question. Five of the above-mentioned behavioural factors of the decision-making process concerning long-term savings coincide with the conclusions of the literature analysis.

\section{Conclusion}

A large and growing body of empirical work has been recently devoted to evaluating the reasons for the low propensity to save for retirement. In this study, the authors adopted the behavioural approach to this phenomenon, analysing what non-economic factors could affect the intention (or lack thereof) to ensure long-term savings.

From this study, the results indicated that the WSL Scale that was developed and validated was a valid and reliable instrument for measuring behavioural aspects of willingness to save long term. The five factors revealed by the Exploratory Factor Analysis (EFA), which were tagged: Confidence in the Pension System, Retirement Anxiety and Emotional Stress, Trust in the Pension System, Attitudes toward Retirement and Long-term Savings and Personal Involvement in Retirement 
Finances, help understand what prevents a significant number of Poles from saving for retirement.

Due to the scarcity of the existing scientific research in this field, about the impact of behavioural factors on long-term savings, there are several possible directions for future work. For example, the investigation could be extended to study the general population of Poles and citizens of other countries to reveal whether other societies differ in terms of the analysed factors, or whether cultural differences are significant.

Therefore, the outcome of the research may affect significantly the process of designing the social message concerning the entire current retirement system. More and more often in public debate it is emphasized that behavioural tools or nudges can help overcome the natural behavioural factors that undermine retirement savings. If one could, by fostering trust in the system, reduce the retirement anxiety and generate positive images of one's old age, one could perhaps influence the growth of voluntary long-term savings for retirement purposes.

\section{References}

Akpochafo, G. O. (2005). A comparative study of anxiety associated with pre-retirement uncertainties of public and private workers: Implications for counselling. The Counsellor, 21, 146-155.

Ameriks, J., Caplin, A., \& Leahy, J. (2003). Wealth accumulation and the propensity to plan. The Quarterly Journal of Economics, 118(3), 1007-1047.

Ballinger, T. P., Hudson, E., Karkoviata, L., \& Wilcox, N. T. (2011). Saving behavior and cognitive abilities. Experimental Economics, (14), 349-374.

Bandalos, D. L. (1993). Factors influencing cross-validation of confirmatory factor analysis models. Multivariate Behavioral Research, (28), 351-374.

Barrafrem, K., Västfjäll, D., \& Tinghög, G. (2020). Financial Homo Ignorans: measuring vulnerability to behavioral biases in household finance (Projects: Financial decision making. Intuition and deliberation in decision making).

Bentler, P. M. (2000). Rites, wrong, and gold in model testing. Structural Equation Modeling, (7), 82-91.

Brzozowska, I. M., \& Goszczyńska, M. (2002). Psychologiczne determinanty skłonności Polaków do oszczędzania. Czasopismo Psychologiczne, 8(2), 201-209.

Carpenter, S. (2018). Ten steps in scale development and reporting: A guide for researchers. Communication Methods and Measures, 12(1), 25-44. doi:10.1080/19312458.2017.1396583

Clifford, S. D. O., Ogbebor, G. G., \& Enakpoya, E. E. (2010). Retirement anxiety and counselling needs of pre-retirees in Delta State. The Counsellor, (27), 76-82.

Czapiński J., \& Góra M. (2016). Świadomość „,emerytalna” Polaków. Raport z badania ilościowego. Warszawa: Europejski Kongres Finansowy.

Elder, H. W., \& Rudolph, P. M. (1999). Does retirement planning affect the level of retirement satisfaction? Financial Services Review, 8(2), 117-127.

Glasman, L. R., \& Albarracín, D. (2006). Forming attitudes that predict future behavior: A meta-analysis of the attitude-behavior relation. Psychological Bulletin, 132(5), 778-822.

Golman, R., Hagmann, D., \& Loewenstein, G. (2017). Information avoidance. Journal of Economic Literature, (55), 96-135.

Gonzalez, R. (2009). Data analysis for experimental design. New York: The Guilford Press. 
Gough, O., \& Sozou, P. D. (2005) Pensions and retirement savings: Cluster analysis of consumer behaviour and attitudes. International Journal of Bank Marketing, 23(7), 558-570.

Hershfield, H. E., Goldstein, D. G., Sharpe, W. F., Fox, J., Yeykelis, L., Carstensen, L. L., \& Bailenson J. N. (2011, November). Increasing Saving Behavior Through Age-Progressed Renderings of the Future Self. Journal of Marketing Research, 48.

Hayslip, B., Bezerlein, M., \& Nichols, S. (1997). Assessing anxiety about retirement: The case of academicians. International Journal of Aging and Human Development, (44), 15-36.

Hightow, L. B., Miller, W. C., Leone, P. A., Wohl, D., Smurzynski, M., \& Kaplan, A. H. (2003). Failure to return for HIV post-test counselling in an STD clinic population. AIDS Education and Prevention, (15), 282-290.

Ho, E. H., Hagmann, D., \& Loewenstein, G. (2020). Measuring Information Preferences. Management Science, 67(1).

Karlsson, N., Loewenstein, G., \& Seppi, D. (2009). The ostrich effect: Selective attention to information. Journal of Risk and Uncertainty, (38), 95-115.

Katona, G. (1975). Psychological Economics. New York: Elsevier.

Mcallister, J. W. (1989). Truth and beauty in scientific reason. Synthese, 78(1), 25-51.

MacCallum, R. C., Widaman, K. F., Zhang, S., \& Hong, S. (1999). Sample size in factor analysis. Psychological Methods, 4(1), 84.

Neukam K. A., \& Hershey D. A. (2003). Financial inhibition, financial activation, and saving for retirement. Financial Services Review, 12, 19-37.

Oluseyi, A. E., \& Olufemi, O. O. (2015). Development and validation of retirement anxiety scale for secondary school teachers in Osun State Nigeria. International Journal of Psychological Studies, $7(2)$.

Raubenheimer, J. (2004). An item selection procedure to maximise scale reliability and validity. Journal of Industrial Psychology, 30(4).

Thaler, R. H., \& Shefrin, H. M. (1981). An economic theory of self-control. Journal of Political Economy, $89(2), 392-406$.

Varian, H. R. (2010). Intermediate microeconomics: A modern approach. New York: W.W. Norton \& Co.

Weber. U. E. (2004). Who's afraid of a poor old-age? Risk perception in risk management decisions. In: O. Mitchell S., S.P. Utkus (Eds.), Pension design and structure: New lessons from behavioral finance. Oxford, UK: Oxford University Press.

\section{BEHAWIORALNE ASPEKTY SKLONNOŚCI DO OSZCZĘDZANIA DLUGOTERMINOWEGO - ANALIZA CZYNNIKOWA}

Streszczenie: W artykule zaprezentowano eksploracyjną analizę czynnikową Skali Gotowości do Oszczędzania Długoterminowego (WSL). Autorski kwestionariusz zawierał 30 pytań dotyczących behawioralnych aspektów mierzących zjawisko gotowości do długoterminowego oszczędzania. Badana populacja obejmowała 232 studentów Wydziału Ekonomii Uniwersytetu Gdańskiego. Wyznaczono dla analizowanej skali wskaźniki rzetelności, a następnie ustalono jej strukturę czynnikową, stosując eksploracyjną analizę czynnikową z rotacją Oblimin. Otrzymane wyniki wykazały, że przeprowadzenie analizy czynnikowej było uzasadnione (KMO $>0,8$, test Bartletta $p<0,001)$. Współczynnik rzetelności $\alpha$ Cronbacha był istotny statystycznie $(0,719)$, wskazując na wysoki stopień spójności wewnętrznej kwestionariusza. Badanie wykazało, że narzędzie WSL było trafnie dobrane i wiarygodne. Pięć ujawnionych czynników może pomóc w lepszym zrozumieniu procesu podejmowania decyzji o długoterminowym oszczędzaniu na cele emerytalne.

Słowa kluczowe: oszczędzanie długoterminowe, gotowość do oszczędzania, eksploracyjna analiza czynnikowa, ekonomia behawioralna. 